\title{
Utility of Isatin Semicarbazones in Mammary Carcinoma Cells - A Proof of Concept Study
}

\author{
Sathianarayanan '", Amrutha B Chittethu', Asha Jose'2, Ranganathan Balasubramanian', Saranya TS', Asha Asokan Manakadan' \\ 'Department of Pharmaceutical Chemistry, Amrita School of Pharmacy, Amrita Vishwa Vidyapeetham, Amrita University, Health Sciences Campus. Kochi, Kerala, INDIA. \\ 2Department of Pharmacology, JSS college of Pharmacy, JSS University. Udhagamandalam, Tamil Nadu, INDIA.
}

\begin{abstract}
Objective: The present study was aimed to determine cytotoxic and apoptotic activity of isatin semicarbazones against mammary carcinoma. Methodology: The preparation of these target compounds involved substitution at the third position of the isatin nucleus along with chemical modification at the nitrogen atom of the scaffold to obtain more potent derivatives. The synthesized analogs were characterized by recording their melting point and $R_{\mathrm{f}}$ values along with $\mathrm{IR}$, NMR and mass spectra. An antioxidant study and Cytotoxic Studies were performed by DPPH, Nitric oxide scavenging method and MTT assay methods. Results: The results revealed that all the test compounds (5a-5d) exhibited good anti oxidant activity. The synthesized compounds were then screened for in-vitro cytotoxicity by MTT cell proliferation assay method against breast cancer cell lines including MCF-7 and BT-549 with derivative 5a exhibiting maximum activity in both the cell lines. DNA fragmentation studies further indicated that $\mathbf{5 a}$ was involved in apoptotic process. Conclusion: Interestingly, it was
\end{abstract}

observed that while all the synthesized compounds seemed active, $\mathbf{5 a}$ exhibited a superior ability to induce apoptosis.

Key words: Anticancer, DNA fragmentation, Isatin, Mammary carcinoma, MTT assay, Antioxidant.

Correspondence :

\section{Sathianarayanan}

'Department of Pharmaceutical Chemistry,

Amrita School of Pharmacy, Amrita Vishwa Vidyapeetham,

Amrita University, Health Sciences Campus. Kochi, Kerala, INDIA

Tel.: +91-9496042083; Fax: +91-0484-2802020

Email: ssnvij@yahoo.co.in

DOI: 10.5530/jyp.2017.9.43

\section{INTRODUCTION}

Isatins comprise a vital class of organic compounds due to their potential activity. Isatin ( $1 H$-indole-2,3-dione) is a versatile scaffold which can be utilized for the synthesis of a large variety of heterocyclic compounds including indoles and quinolines. Isatin derivatives have been identified to possess a useful pharmacophore associated with wide spectrum of pharmacological activities like antibacterial, ${ }^{1}$ anticonvulsant, ${ }^{2}$ antitubercular, ${ }^{3}$ analgesic, ${ }^{4}$ anti-inflammatory, ${ }^{5}$ antiviral, ${ }^{6}$ anti-HIV, ${ }^{7}$ antifungal ${ }^{8}$ effects. The possibility of a multitude of unique chemical structures such as those obtained by substitution of the aryl ring, alkylation of the nitrogen atom in the moiety and also modifications in the $\mathrm{C}_{2}$ and/or $\mathrm{C}_{3}$ carbonyl functionalities by derivatization of the isatin nucleus facilitates diverse biochemical targeting.

Cancer is a family of diseases pertaining to abnormal complexity in the cell physiology and among these, breast cancer is one of the most frequently encountered types that is attributed to death. This has been observed to be the second most prevalent variety of cancer after lung cancer and is the fifth common cause of cancer ascribing to deaths worldwide. ${ }^{9}$ Women over the age of forty bear the chances of being afflicted with breast cancer with the propensity of risk elevating in women of older age. ${ }^{10}$ Many hormones and enzymes are involved in the development of this condition which accounts for nearly seven million deaths worldwide annually. It is estimated that by 2020 , the mortality due to breast cancer will be more than with any other cancer type. According to statistical data released by Indian Council of Medical Research (ICMR), one in 22 women in India is likely to suffer from breast cancer during their lifetime. In contrast, one in eight women in the United States is a victim of this deadly cancer. ${ }^{11}$
Apoptosis, also known as programmed cell death, is a complex cellular process involving the elimination of the diseased, damaged or senescent cells from the body. Besides, apoptosis is an effective and important pathway in antitumor drug response. ${ }^{12}$ Although considerable advances have been made in recent decades in the research and development of various cancer chemotherapeutic drugs, current antitumor therapies still have certain limitations. Therefore there is a need to discover and develop useful lead compounds of simple structure, exhibiting optimal antitumor potency. The development of an effective agent that triggers apoptosis might be a promising strategy in the treatment of cancer. ${ }^{13}$ Therefore in our attempt to seek out cytotoxic molecules with simple structures, this study reveals a set of isatin semicarbazone derivatives with potential application against mammary carcinoma cell lines. Furthermore, a preliminary investigation about their ability to induce apoptosis was carried out using $5 \mathrm{a}$ as a test compound in order to explain the mechanistic basis of cytotoxicity.

\section{MATERIALS AND METHODS}

All the commercial reagents procured were of GR/AR grade and the reactions were carried out in dried borosil glass vessels. The compounds synthesized were characterized using TLC, melting point, IR, NMR and mass spectra. TLC was performed on silica gel $G F_{254}$ (Merck aluminium plate) as the stationary phase and ethyl acetate: $n$-butanol: water $(6: 3: 1)$ as the mobile phase. Iodine chamber was used for detection of the spots. Melting points were determined using capillary tubes on Veego-VMP apparatus and are uncorrected. All microwave syntheses were carried out in Catalyst ${ }^{\mathrm{Tm}}$ Systems CATA 2 R Scientific Microwave Synthesizer

This is an open access article distributed under the terms of the Creative Commons Attribution-NonCommercial-ShareAlike 4.0 License, which allows others to remix, tweak, and build upon the work non-commercially, as long as the author is credited and the new creations are licensed under the identical terms. 
with ten different power settings. The IR spectra of the synthesized compounds were recorded on a Shimadzu-FTIR spectrometer (IR Affinity 1) using potassium bromide pellet technique. ${ }^{1} \mathrm{H}$ and ${ }^{13} \mathrm{C}$ NMR of the compounds were recorded using Bruker Spectrospin $400 \mathrm{MHz}$ spectrometer with tetramethylsilane (TMS) as internal standard. Deuterated dimethyl sulfoxide $\left[\left(\mathrm{CD}_{3}\right)_{2} \mathrm{SO}_{2}\right]$ was used as the solvent for recording these spectra and the chemical shift was expressed as delta values relative to TMS in units of ppm. Mass spectra of the samples were recorded on MSMS-QP 5050 Shimadzu instrument.

MCF-7 and BT-549 (human breast carcinoma) cell lines were procured from National Centre for Cell Sciences (NCCS), Pune, India. 3-(4,5-Dimethylthiazol-2-yl)-2,5-diphenyltetrazolium bromide (MTT), Fetal Bovine Serum (FBS), Phosphate Buffered Saline (PBS), Dulbecco's Modified Eagle's Medium (DMEM) \& trypsin were obtained from Sigma Aldrich Co, St. Louis, USA; EDTA, glucose \& antibiotics from Hi-Media Laboratories Ltd., Mumbai, India and dimethyl sulfoxide (DMSO) \& propanol procured from E.Merck Ltd., Mumbai, India. In-vitro antioxidant activity was determined using Shimadzu UV-Vis spectrophotometer; MTT assay was carried out in Beckmann coulter Elisa plate reader (BioTek Power wave XS) and fragmented DNA was visualized by UV transilluminator (Ultra-Lum Electronic UV transilluminator, USA).

\section{Synthesis}

The isatin derivatives of interest in this study (5a-5d) were prepared in a convergent fashion as illustrated in Figure 1: the precursors being a $N$-protected isatin 2 and four substituted phenyl semicarbazides $\mathbf{4 a}, \mathbf{4 b}$, $\mathbf{4 c}$ and $4 \mathbf{d}$. The reaction sequence pertaining to the assembly of the target compounds includes alkylation at the nitrogen atom of the isatin scaffold, a nucleophilic addition to place a urea moiety and the eventual condensation of these two preformed precursors ${ }^{14}$ Subsequent spectral characterization helped confirm the structure of the synthesized derivatives in an unambiguous manner.

Preparation of 2,3-dioxo-2,3-dihydro-indol-1-yl-acetic acid hydrazide 2 To $147 \mathrm{mg}(0.001 \mathrm{~mol})$ of isatin dissolved in $2 \mathrm{ml}$ of dimethylformamide (DMF) was added $1.23 \mathrm{ml}(0.01 \mathrm{~mol})$ of ethyl chloroacetate followed by $0.138 \mathrm{~g}(0.001 \mathrm{~mol})$ of potassium carbonate. The mixture was then kept in a microwave oven (90 watt) for $10 \mathrm{~min}$ and maintained at $80^{\circ} \mathrm{C}$. Subsequent to TLC analysis that ensured completion of the reaction, a small amount of cold water was added to the mixture and shaken well. The separated solid was filtered, washed with excess of cold water and dried. The compound prepared above was dissolved in $2.5 \mathrm{ml}$ of ethanol to ensure complete dissolution at room temperature. To this solution hydrazine hydrate $0.25 \mathrm{ml}(0.006 \mathrm{~mol})$ was added and the resultant mixture was stirred at room temperature for $15 \mathrm{~min}$ following which it was kept in microwave oven (90 watt) for 5 min while being maintained at $50^{\circ} \mathrm{C}$. The yellow powder obtained was washed with methanol to afford the target compound that was used directly for the final condensation reaction.

\section{General procedure for the synthesis of $\mathbf{4 a - 4 d}$}

Appropriate monosubstituted anilines $\mathbf{3 a}-\mathbf{3 d}(0.1 \mathrm{~mol})$ were ground in a glass mortar and dissolved in a mixture of $10 \mathrm{ml}(0.17 \mathrm{~mol})$ glacial acetic acid and $90 \mathrm{ml}$ water. A solution of sodium cyanate $(0.1 \mathrm{~mol})$ in $50 \mathrm{ml}$ of water at $35^{\circ} \mathrm{C}$ was gradually added to the amine solution with continuous stirring and the resultant mixture allowed to stand for $30 \mathrm{~min}$. After refluxing the mixture for 2-3 h, the resultant solution was cooled in ice for 30 min upon which a colorless crystalline solid precipitated. This crude phenylurea intermediate was washed with a mixture of acetic acid and water before being taken for next step. To an aqueous solution of substituted phenylurea $(0.01 \mathrm{~mol})$ containing $20 \mathrm{ml}$ of water, hydrazine hydrate $(0.1 \mathrm{~mol})$ was added. The reaction mixture was completely solubilized using ethanol $(10 \mathrm{ml})$ and made alkaline $(\sim \mathrm{pH} 13)$ by the addition of saturated aqueous sodium hydroxide. The ethanolic solution was then heated under reflux for about $3 \mathrm{~h}$ and cooled in ice. The precipitate was filtered and washed with ethanol yielding the corresponding substituted phenyl semicarbazides $\mathbf{4 a - 4 d}$ as crystalline solids.

\section{General procedure for condensation}

An alcoholic solution of $0.01 \mathrm{~mol}$ of an appropriate phenyl semicarbazide was slowly added to a $0.01 \mathrm{~mol}$ alcoholic solution of the alkylated isatin 2 . This was followed by the addition of glacial acetic acid $(5 \mathrm{ml})$ and refluxing the mixture for $30 \mathrm{~min}$. After washing the product obtained with a mixture of ether and water, the solids were typically recrystallized to purity from methanol.

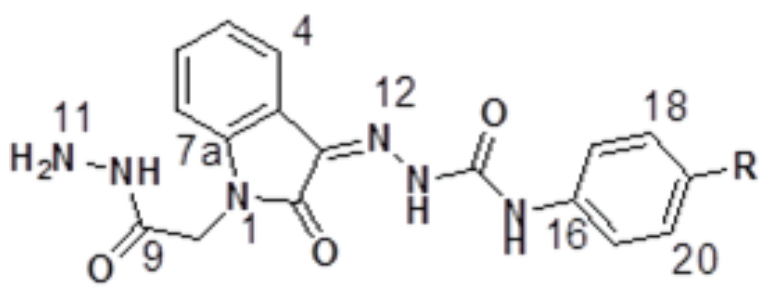

N-(4-Fluorophenyl)-2-[1-(2-hyrdazinyl-2-oxoethyl)-2-oxo-1,2-dihydro$3 \mathrm{H}$-indole-3-ylidene]hydrazinecarboxamide 5a: Yellowish crystalline powder; overall yield 26\%; $R_{\mathrm{f}}=0.62$ (ethyl acetate:methanol:water $\{6: 4: 1\}) ; \mathrm{mp} 110-112{ }^{\circ} \mathrm{C}$; IR (KBr) cm $\mathrm{cm}^{-1}: 3356$ (NH stretching), 1681 $(\mathrm{C}=\mathrm{O}), 1652(\mathrm{C}=\mathrm{N}), 1587(\mathrm{C}=\mathrm{C}), 1465(\mathrm{CONH}), 748$ (aromatic para substitution); ${ }^{1} \mathrm{H}$ NMR $\left(\left(\mathrm{CD}_{3}\right)_{2} \mathrm{SO}, 400 \mathrm{MHz}\right) \delta 10.70(1 \mathrm{H}, \mathrm{s}, \mathrm{N} 10-\mathrm{H})$, $10.56\left(2 \mathrm{H}, \mathrm{d}, J=7.4 \mathrm{~Hz}, \mathrm{~N} 11-\mathrm{H}_{2}\right), 9.58(1 \mathrm{H}, \mathrm{d}, J=7.2 \mathrm{~Hz}, \mathrm{~N} 13-\mathrm{H})$, $9.54(1 \mathrm{H}, \mathrm{d}, J=7.4 \mathrm{~Hz}, \mathrm{~N} 15-\mathrm{H}), 7.36(2 \mathrm{H}, \mathrm{d}, J=7.2 \mathrm{~Hz}, \mathrm{C} 17-\mathrm{H}, \mathrm{C} 21-\mathrm{H})$, 7.23-7.14 (2H, m, C4-H, C7-H), 7.07-6.95 (2H, m, C5-H, C6-H), 6.86 $(2 \mathrm{H}, \mathrm{d}, J=7.6 \mathrm{~Hz}, \mathrm{C} 18-\mathrm{H}, \mathrm{C} 20-\mathrm{H}), 3.35\left(2 \mathrm{H}, \mathrm{s}, \mathrm{C} 8-\mathrm{H}_{2}\right) ;{ }^{13} \mathrm{C} \mathrm{NMR}$ $\left(\left(\mathrm{CD}_{3}\right)_{2} \mathrm{SO}, 100 \mathrm{MHz}\right) \delta 165.8(\mathrm{C} 9=\mathrm{O}), 162.8(\mathrm{C} 2=\mathrm{O}), 156.1(\mathrm{C} 14=\mathrm{O})$, 140.5 (C19-F), 138.6 (C7a), 128.6 (C16), 127.0 (C17, C21), 126.2 (C4, C7), 122.2 (C5, C6), $119.2(\mathrm{C} 3 \mathrm{a}), 115.1(\mathrm{C} 18, \mathrm{C} 20), 109.9(\mathrm{C} 3=\mathrm{N})$, 65.7 (C8); ESI MS ( $\mathrm{m} / \mathrm{z}$, relative abundance) $393\left[(\mathrm{M}+\mathrm{Na})^{+}, 100 \%\right]$.

$\mathrm{N}$-(4-Chlorophenyl)-2-[1-(2-hyrdazinyl-2-oxoethyl)-2-oxo-1,2-dihydro$3 \mathrm{H}$-indole-3-ylidene]hydrazinecarboxamide $\mathbf{5} \boldsymbol{b}$ : Pale yellow crystalline powder; overall yield 24\%; $R_{\mathrm{f}}=0.61$ (ethyl acetate:methanol:water $\{6: 4: 1\}) ; \mathrm{mp} 92-96{ }^{\circ} \mathrm{C}$; IR (KBr) $\mathrm{cm}^{-1}$ : 3358 (NH stretching), 1683 $(\mathrm{C}=\mathrm{O}), 1656(\mathrm{C}=\mathrm{N}), 1589(\mathrm{C}=\mathrm{C}$ aromatic stretching $), 1464(\mathrm{CONH})$, 748 (aromatic para substitution); ${ }^{1} \mathrm{H}$ NMR $\left(\left(\mathrm{CD}_{3}\right)_{2} \mathrm{SO}, 400 \mathrm{MHz}\right)$ $\delta 10.70(1 \mathrm{H}, \mathrm{s}, \mathrm{N} 10-\mathrm{H}), 10.54\left(2 \mathrm{H}, \mathrm{d}, J=14 \mathrm{~Hz}, \mathrm{~N} 11-\mathrm{H}_{2}\right), 9.57(1 \mathrm{H}$, d, $J=7.6 \mathrm{~Hz}, \mathrm{~N} 13-\mathrm{H}), 9.54(1 \mathrm{H}, \mathrm{d}, J=7.4 \mathrm{~Hz}, \mathrm{~N} 15-\mathrm{H}), 7.36(2 \mathrm{H}, \mathrm{d}$, $J=7.2 \mathrm{~Hz}, \mathrm{C} 17-\mathrm{H}, \mathrm{C} 21-\mathrm{H}), 7.16(2 \mathrm{H}, \mathrm{t}, J=7.6 \mathrm{~Hz}, \mathrm{C} 4-\mathrm{H}, \mathrm{C} 7-\mathrm{H}), 6.97$ $(2 \mathrm{H}, \mathrm{t}, J=7.6 \mathrm{~Hz}, \mathrm{C} 5-\mathrm{H}, \mathrm{C} 6-\mathrm{H}), 6.87(2 \mathrm{H}, \mathrm{d}, J=8 \mathrm{~Hz}, \mathrm{C} 18-\mathrm{H}, \mathrm{C} 20-\mathrm{H})$, $3.39\left(2 \mathrm{H}, \mathrm{s}, \mathrm{C} 8-\mathrm{H}_{2}\right) ;{ }^{13} \mathrm{C} \mathrm{NMR}\left(\left(\mathrm{CD}_{3}\right)_{2} \mathrm{SO}, 100 \mathrm{MHz}\right) \delta 165.7(\mathrm{C} 9=\mathrm{O})$, 162.7 (C2=O, C14=O), 140.5 (C19-Cl), 138.6 (C7a), 128.5 (C16), 127.0 (C17, C21), 126.2 (C4, C7), 122.2 (C6), 121.3 (C5), 119.6 (C3a), 117.4 $(\mathrm{C} 18, \mathrm{C} 20), 109.9(\mathrm{C} 3=\mathrm{N}), 74.1(\mathrm{C} 8)$; ESI MS $(\mathrm{m} / z$, relative abundance $)$ $386\left[\mathrm{M}^{+}, 100 \%\right]$.

N-(4-Bromophenyl)-2-[1-(2-hyrdazinyl-2-oxoethyl)-2-oxo-1,2-dihydro$3 \mathrm{H}$-indole-3-ylidene]hydrazinecarboxamide $5 \mathrm{c}$ : Dark yellow crystalline powder; overall yield $27 \% ; R_{\mathrm{f}}=0.64$ (ethyl acetate:methanol:water $\{6: 4: 1\}) ; \mathrm{mp} 118-120{ }^{\circ} \mathrm{C}$; IR ( $\left.\mathrm{KBr}\right) \mathrm{cm}^{-1}: 3356$ (NH stretching), 1683 $(\mathrm{C}=\mathrm{O}), 1651(\mathrm{C}=\mathrm{N}), 1587(\mathrm{C}=\mathrm{C}), 1465(\mathrm{CONH}), 748$ (aromatic para substitution); ${ }^{1} \mathrm{H}$ NMR $\left(\left(\mathrm{CD}_{3}\right)_{2} \mathrm{SO}, 400 \mathrm{MHz}\right) \delta 10.70(1 \mathrm{H}, \mathrm{s}, \mathrm{N} 10-\mathrm{H})$, $10.56\left(2 \mathrm{H}, \mathrm{d}, J=14 \mathrm{~Hz}, \mathrm{~N} 11-\mathrm{H}_{2}\right), 9.58(1 \mathrm{H}, \mathrm{d}, J=7.4 \mathrm{~Hz}, \mathrm{~N} 13-\mathrm{H}), 9.54$ $(1 \mathrm{H}, \mathrm{s}, \mathrm{N} 15-\mathrm{H}), 7.91(2 \mathrm{H}, \mathrm{d}, J=7.6 \mathrm{~Hz}, \mathrm{C} 17-\mathrm{H}, \mathrm{C} 21-\mathrm{H}), 7.36(1 \mathrm{H}, \mathrm{t}$, $J=5.2 \mathrm{~Hz}, \mathrm{C} 6-\mathrm{H}), 7.22-7.14(2 \mathrm{H}, \mathrm{m}, \mathrm{C} 4-\mathrm{H}, \mathrm{C} 7-\mathrm{H}), 6.99-6.94(2 \mathrm{H}, \mathrm{m}$, C18-H, C20-H), $6.85(1 \mathrm{H}, \mathrm{t}, J=7.8 \mathrm{~Hz}, \mathrm{C} 5-\mathrm{H}), 3.59\left(2 \mathrm{H}, \mathrm{s}, \mathrm{C} 8-\mathrm{H}_{2}\right)$; ${ }^{13} \mathrm{C}$ NMR $\left(\left(\mathrm{CD}_{3}\right)_{2} \mathrm{SO}, 100 \mathrm{MHz}\right) \delta 165.8(\mathrm{C} 9=\mathrm{O}), 162.8(\mathrm{C} 2=\mathrm{O}), 155.8$ 
(C14=O), 140.5 (C19-Br), 139.9 (C7a), 138.6 (C16), 131.2 (C17), 128.6 (C21), 127.0 (C4), 126.2 (C7), 122.7 (C6), 122.2 (C5), 121.3 (C3a), 119.6 (C18), $116.9(\mathrm{C} 20), 109.9(\mathrm{C} 3=\mathrm{N}), 64.3(\mathrm{C} 8)$; ESI MS $(\mathrm{m} / \mathrm{z}$, relative abundance) $431\left[\mathrm{M}^{+}, 100 \%\right]$.

$\mathrm{N}$-(4-Nitrophenyl)-2-[1-(2-hyrdazinyl-2-oxoethyl)-2-oxo-1,2-dihydro$3 \mathrm{H}$-indole-3-ylidene]hydrazinecarboxamide 5d: Pale yellow crystalline powder; overall yield 28\%; $R_{\mathrm{f}}=0.62$ (ethyl acetate:methanol:water \{6:4:1\}); mp 93-96 ${ }^{\circ} \mathrm{C}$; IR (KBr) cm ${ }^{-1}: 3356$ ( NH stretching), $1682(\mathrm{C}=\mathrm{O})$, $1652(\mathrm{C}=\mathrm{N}), 1587(\mathrm{C}=\mathrm{C}), 1553\left(\mathrm{NO}_{2}\right), 1465(\mathrm{CONH}), 750$ (aromatic para substitution); ${ }^{1} \mathrm{H}$ NMR $\left(\left(\mathrm{CD}_{3}\right)_{2} \mathrm{SO}, 400 \mathrm{MHz}\right) \delta 10.71(1 \mathrm{H}, \mathrm{d}$, $J=14.4 \mathrm{~Hz}, \mathrm{~N} 10-\mathrm{H}), 10.58-10.55\left(2 \mathrm{H}, \mathrm{m}, \mathrm{N} 11-\mathrm{H}_{2}\right), 9.59-9.55(2 \mathrm{H}, \mathrm{m}$, N13-H, N15-H), $7.38(2 \mathrm{H}, \mathrm{d}, J=7.6 \mathrm{~Hz}, \mathrm{C} 17-\mathrm{H}, \mathrm{C} 21-\mathrm{H}), 7.17(2 \mathrm{H}, \mathrm{t}$, $J=7.4 \mathrm{~Hz}, \mathrm{C} 4-\mathrm{H}, \mathrm{C} 7-\mathrm{H}), 6.98(2 \mathrm{H}, \mathrm{t}, J=7.4 \mathrm{~Hz}, \mathrm{C} 5-\mathrm{H}, \mathrm{C} 6-\mathrm{H}), 6.88(2 \mathrm{H}, \mathrm{d}$, $J=7.6 \mathrm{~Hz}, \mathrm{C} 18-\mathrm{H}, \mathrm{C} 20-\mathrm{H}), 3.40\left(2 \mathrm{H}, \mathrm{s}, \mathrm{C} 8-\mathrm{H}_{2}\right) ;{ }^{13} \mathrm{C} \mathrm{NMR}\left(\left(\mathrm{CD}_{3}\right)_{2} \mathrm{SO}\right.$, $100 \mathrm{MHz}) \delta 165.8(\mathrm{C} 9=\mathrm{O}), 162.8(\mathrm{C} 9=\mathrm{O}, \mathrm{C} 14=\mathrm{O}), 140.5\left(\mathrm{C} 19-\mathrm{NO}_{2}\right)$, 138.6 (C7a), 128.6 (C16), 127.0 (C17, C21), 126.2 (C4, C7), 122.7 (C5, C6), 122.2 (C3a), 117.4 (C18, C20), $109.9(\mathrm{C} 3=\mathrm{N}), 74.2$ (C8); ESI MS $(\mathrm{m} / \mathrm{z}$, relative abundance $) 437\left[(\mathrm{M}+\mathrm{K})^{+}, 20 \%\right]$.

\section{Determination of biological activity}

\section{Antioxidant activity by DPPH method}

A $0.1 \mathrm{mM}$ solution of DPPH in methanol ${ }^{15,16}$ was prepared and $1 \mathrm{ml}$ of this solution was added to $3 \mathrm{ml}$ of sample solution in water at different concentrations. ${ }^{17}$ This mixture was vortexed and kept in the dark for equilibration at $25^{\circ} \mathrm{C}$. After a 30 min incubation time, the absorbance was taken at $517 \mathrm{~nm}$ using UV-Vis spectrophotometer and the half maximal inhibitory concentration $\left(\mathrm{IC}_{50}\right.$ ) values calculated. Ascorbic acid was used as a standard.

\section{Antioxidant activity by nitric oxide scavenging method}

A mixture of $0.5 \mathrm{ml}$ of sample, $0.5 \mathrm{ml}$ of phosphate buffer ( $\mathrm{pH} 7.4$ ) and 2 $\mathrm{ml}$ sodium nitroprusside solution was prepared ${ }^{18}$ and incubated at $25^{\circ} \mathrm{C}$ for $2 \mathrm{~h}$. A $0.5 \mathrm{ml}$ aliquot of this reaction mixture was pipetted out and mixed with $1 \mathrm{ml}$ of sulphanilic acid and allowed to stand for $5 \mathrm{~min}$ for complete diazotization. To this mixture, $1 \mathrm{ml}$ of $0.1 \% n$-naphthyl ethylene diamine dihydrochloride was added and allowed to stand for $30 \mathrm{~min}$ to form a pink colored chromophore. Absorbance was then measured at $530 \mathrm{~nm}$ against the corresponding blank solution and $\mathrm{IC}_{50}$ values determined. Ascorbic acid once again served as a standard in this assay.

\section{Assessment of cytotoxicity by MTT assay}

The potential of the synthesized isatin derivatives to maintain cell viability was tested using the MTT assay method against MCF-7 as well as BT-549 cells lines ${ }^{19}$ The assay principle involves the reductive cleavage of tetrazolium salt 3-(4,5-dimethylthiazole-2-yl)-2,5-diphenyltetrazolium bromide (MTT) to a blue colored insoluble product formazan by mitochondrial enzyme succinate dehydrogenase. ${ }^{20}$ The number of viable cells was found to be proportional to the extent of formazan production by the cells used.

These tests, which depend on the ability of cells to survive a toxic insult, were carried out by using 96-well microtitre plates. Each well of 96-well plate was seeded with $0.1 \mathrm{ml}$ of cultured cell (MCF-7/BT-549 cell count was adjusted to $1 \mathrm{X} 10^{5}$ cells/ml using DMEM medium containing $10 \%$ of FBS), suspended into cultural medium and incubated for $24 \mathrm{~h}$ at $37^{\circ} \mathrm{C}$ in $5 \%$ carbon dioxide $\left(\mathrm{CO}_{2}\right)$ incubator. The monolayer cells were washed with medium and exposed to different concentrations of synthesized compounds. The incubation under the above mentioned conditions was carried out for three days. After that the tested solution in the wells were discarded and $50 \mu \mathrm{l}$ of MTT in PBS was added to each cell. The plates were incubated at $37^{\circ} \mathrm{C}$ in $5 \% \mathrm{CO}_{2}$ incubator for $5 \mathrm{~h}$. The stable blue color compound formed was estimated by colorimetric method. The absorbance was measured using a microplate reader at a wavelength of $540 \mathrm{~nm} .{ }^{21}$ The vehicle control was designated as the well containing live cells with the culture medium..$^{22}$ The percentage growth inhibition was calculated using the formula depicted below and concentration of test drug needed to inhibit cell growth by $50 \%$ i.e., the half maximal cytotoxic inhibitory concentration $\left(\mathrm{CTC}_{50}\right.$ values) generated from the dose-response curves for each cell line. ${ }^{23}$ The inhibition of cell growth in vehicle control was zero percentage. Tamoxifen was used as a standard. Moreover, the absorbance associated with the DMSO blank was subtracted from the absorbance readings of test compounds, standard and vehicle control.

Percentage inhibition $=1-($ mean OD of test compound $/$ mean OD of vehicle control) $\times 100$

\section{DNA fragmentation as a means to determine apoptotic ability via DNA ladder assay}

MCF-7 cells were seeded into $60 \mathrm{~mm}$ petri dish $^{24}$ and incubated at $37^{\circ} \mathrm{C}$ (under $5 \% \mathrm{CO}_{2}$ atmosphere) for $24 \mathrm{~h}$. The cells were washed with medium and then treated with different doses of the test compound followed by another incubation at $37^{\circ} \mathrm{C}$ for $24 \mathrm{~h}$ in a $5 \% \mathrm{CO}_{2}$ atmosphere. As the incubation time ends, the chromosomal DNA of cancer cells was prepared. The eluted $\mathrm{DNA}^{25}$ was loaded onto $2 \%$ agarose gel and electrophoresis performed at $50 \mathrm{~V} / \mathrm{cm}$ for $3 \mathrm{~h}$. Visualization of the gel was carried out using UV transilluminator and the image photographed.

\section{Statistical analysis}

All assays were carried out in triplicate, and the values were expressed as mean \pm SEM. The results were statistically analyzed by one way ANOVA.

\section{RESULTS AND DISCUSSION}

\section{Chemistry}

The target compounds which were synthesized via a convergent three step sequence (Figure 1) were characterized by standard spectroscopic techniques and their purity ascertained by routine TLC analysis along with melting point determination. One branch of overall route involves the alkylation of the nitrogen atom of isatin leading to the acetic acid hydrazide 2. This transformation, in turn, is achieved in two sequential steps: (i) blocking the N-H group of isatin using ethyl chloroacetate in the presence of a base and (ii) displacing the ethoxy group to put in place the desired hydrazide functionality. The other portion leading upto the various phenyl semicarbazadies $\mathbf{4 a}-\mathbf{4 d}$ proceeds via the intermediacy of urea moieties that are obtained by the reaction of appropriate parasubstituted anilines with sodium cyanate. The urea is converted into the corresponding semicarbazide upon reaction with the nucleophile hydrazine hydrate. The convergent assembly of isatin derivatives is completed by condensation of compounds $\mathbf{4 a}-\mathbf{4 d}$ with the common intermediate $\mathbf{2}$ to yield four target hydrazine carboxamides $\mathbf{5 a - 5 d}$.

IR spectral data consistently showed strong bands in the narrow range between $1681-1683 \mathrm{~cm}^{-1}$ and $3356-3358 \mathrm{~cm}^{-1}$ suggesting the presence of carbonyl $(\mathrm{C}=\mathrm{O})$ and $\mathrm{NH}$ functional groups respectively. In addition to these features, absorption band at $1553 \mathrm{~cm}^{-1}$ is seen in the nitro substituted compound. Structures of all compounds were established by ${ }^{1} \mathrm{H}$ and ${ }^{13} \mathrm{C}$ NMR spectral analysis. The formation of the desired compounds was further confirmed by means of analyzing their mass spectra. The bromo derivative $\mathbf{5} \mathbf{c}$ showed the presence of $\mathrm{M}^{+}$peak $(\mathrm{m} / z 431)$; $\mathbf{5 b}$ also showed $\mathbf{M}^{+}$peak $(m / z 386)$ an appropriate molecular ion confirming the molecular weight of the synthesized target compounds. While derivatives $\mathbf{5 d}$ showed $(\mathrm{M}+\mathrm{K})^{+}$peak, the mass spectrum of congener 5a contained $(\mathrm{M}+\mathrm{Na})^{+}$peak. Thus, by determining melting point and $R_{\mathrm{f}}$ values along with the detailed interpretation of IR, NMR and mass 
spectra, the synthesized compounds (5a-5d) were found to be pure and identified chemically.

\section{Pharmacological evaluation}

\section{Assessment of antioxidant activity}

In-vitro antioxidant potential of the target isatin derivatives was assessed by the well-established DPPH and nitric oxide scavenging methods. The body's inbuilt antioxidant mechanism can be divided into an enzymatic and a non-enzymatic system. The enzymatic defense system includes superoxide dismutase (SOD), catalase (CAT), glutathione peroxidase (GPx) and glutathione reductase (GR) while the non-enzymatic arm incorporates vitamin $\mathrm{C}$ and reduced glutathione (GSH). Free radicals are highly reactive molecules containing unpaired (odd) electrons that cause oxidative stress - a condition that is characterized by an imbalance between oxidants and antioxidants in favor of the oxidants, potentially leading to damage. Free radicals and other oxygen based species which are partially reduced forms of atmospheric oxygen $\left(\mathrm{O}_{2}\right)$ are collectively known as reactive oxygen species (ROS). These are produced by normal physiological processes; more so under pathological conditions and typically result from the excitation of oxygen $\left(\mathrm{O}_{2}\right)$ to form singlet oxygen $\left({ }^{1} \mathrm{O}_{2}\right)$ or via the transfer of one or more electrons to form a superoxide radical $\left(\mathrm{O}_{2}^{-}\right)$, hydrogen peroxide $\left(\mathrm{H}_{2} \mathrm{O}_{2}\right)$ or a hydroxy radical (HO), respectively. ${ }^{26}$ The generation of these reactive oxygen species has also been linked to some neurodegenerative disorders and cancers. Typically, the free radicals formed are degraded simultaneously to non-reactive forms by the two types of antioxidant defense mechanisms viz. enzymatic and non-enzymatic.

The 1,1-diphenyl-2-picrylhydrazyl (DPPH) methodology involves the donation of a proton from a suitable hydrogen atom donor forming the reduced DPPH. After reduction, the observed color change from purple to yellow is quantified by its low absorbance at a wavelength of $517 \mathrm{~nm}$. Electrons become paired off and the solution loses color stoichiometrically depending on the number of electrons taken up. The radical scavenging activity of the synthesized isatin derivatives was evident at all concentrations between 10 and $50 \mu \mathrm{g} / \mathrm{ml}$ and in fact, increased with an increase in concentration Table 1 of the test compounds. Among the four analogs tested, $\mathbf{5 d}$ exhibited maximum activity with $\mathrm{IC}_{50}$ value 20.23 $\mu \mathrm{g} / \mathrm{ml}$ in this assay. While the fluoro (5a) and bromo (5c) derivatives displayed moderate activity ( $\mathrm{IC}_{50} 5 \mathrm{a}: 21.04 \& \mathrm{IC}_{50} \mathbf{5 c}: 23.42 \mu \mathrm{g} / \mathrm{ml}$ ), the chloro congener $\mathbf{5 b}$ showed the lowest scavenging activity with the highest $\mathrm{IC}_{50}$ value $24.81 \mu \mathrm{g} / \mathrm{ml}$ when compared to standard ascorbic acid $\left(\mathrm{IC}_{50}\right.$ value $19.54 \mu \mathrm{g} / \mathrm{ml}$ ).

The nitric oxide scavenging method involves the generation of nitric oxide (NO) from sodium nitroprusside. The reaction of NO with oxygen forming nitrite is often inhibited by antioxidants or nitric oxide scavengers that compete with oxygen for the available NO. Therefore, when sodium nitroprusside is incubated in the presence of potential antioxidants, such as the target isatin compounds in this study, the amount of NO generated will be less. The excess NO is then estimated by Griess reagent, a mixture of sulphanilic acid and $n$-napthyl ethylene diamine dihydrochloride. Analogous to the previous assay, a concentration dependent percentage inhibition was observed. As evident from Table 2, test compound $5 \mathrm{a}$ with an $\mathrm{IC}_{50}$ value $26.81 \mu \mathrm{g} / \mathrm{ml}$ showed potent antioxidant ability comparable to that of standard ascorbic acid $\left(\mathrm{IC}_{50}\right.$ value $27.21 \mu \mathrm{g} / \mathrm{ml}$ ). Chemically, $\mathrm{NO}$ is a free radical derived from the oxidation of terminal guanidine nitrogen atom of 1 -arginine by nitric oxide synthase (NOS). ${ }^{27}$ Activated macrophages transcriptionally express inducible NOS (iNOS), which is responsible for the prolonged and profound production of NO. This uncharacteristic release of NO leads to amplification of inflammation as well as tissue injury. Therefore, inhibition of NO production represents an important therapeutic approach in the development of anti-inflammatory agents. The good nitric oxide scavenging activity displayed by the test compounds indicates that they may possess potential anti-inflammatory property. It is now understood that NOS facilitates tumor progression and its inhibition enhances apoptosis. Moreover, it has been reported that inhibition of NO in tumor conditions could regulate the mammary epithelial growth and tumor progression. ${ }^{28}$ Targeted modulation of NO levels could therefore be a feasible approach for breast cancer treatment.

\section{Determination of cytotoxicity}

The mitochondrial TCA cycle plays a key role in the process of tumorigenesis. In cancer cells, presence of the four-subunit enzyme succinate dehydrogenase $(\mathrm{SDH})$ alters the mitochondrial TCA cycle. The subunits, identified as SDHA, SDHB, SDHC and SDHD are present on the inner membrane of mitochondria and participate in both the TCA cycle as well as the respiratory chain wherein they induce the growth of cancer cells. The in-vitro anticancer screening of all the prepared compounds was carried out by MTT assay in MCF- 7 and BT-549 cell lines. The MTT assay is based on the assumption that living cells reduce tetrazolium due to the presence of mitochondrial SDH, which is absent in the metabolically

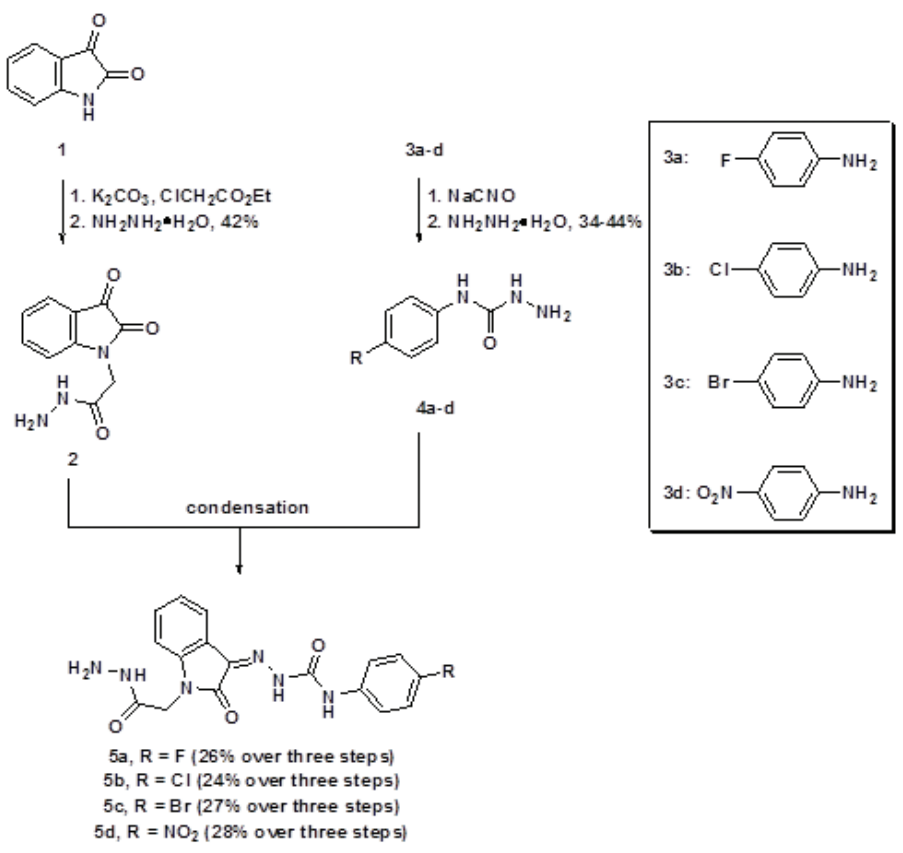

Figure 1: Convergent synthesis of target isatin derivatives.

Table 1: DPPH radical scavenging activity

\begin{tabular}{ccccc}
\hline Concentration & \multicolumn{4}{c}{ Percentage inhibition } \\
\hline$(\mu \mathrm{g} / \mathrm{ml})$ & $5 \mathrm{a}$ & $5 \mathrm{~b}$ & $5 \mathrm{c}$ & $5 \mathrm{~d}$ \\
\hline 10 & $25.29 \pm 0.35$ & $26.22 \pm 0.68$ & $27.85 \pm 0.61$ & $26.52 \pm 0.63$ \\
20 & $46.46 \pm 0.48$ & $45.61 \pm 0.43$ & $44.95 \pm 0.81$ & $49.98 \pm 0.59$ \\
30 & $56.54 \pm 0.96$ & $57.42 \pm 0.62$ & $55.13 \pm 0.61$ & $56.82 \pm 0.59$ \\
40 & $67.68 \pm 0.62$ & $66.47 \pm 0.64$ & $63.43 \pm 0.69$ & $65.34 \pm 0.66$ \\
50 & $71.72 \pm 0.23$ & $70.64 \pm 0.54$ & $69.41 \pm 0.66$ & $72.10 \pm 0.36$ \\
\hline
\end{tabular}

Reference standard - ascorbic acid

Concentration and percentage inhibition of ascorbic acid: $10 \mu \mathrm{g} / \mathrm{ml}: 32.16 \pm 0.34$, $20 \mu \mathrm{g} / \mathrm{ml}: 51.74 \pm 0.78$,

$30 \mu \mathrm{g} / \mathrm{ml}: 66.51 \pm 0.19,40 \mu \mathrm{g} / \mathrm{ml}: 78.14 \pm 0.23$ and $50 \mu \mathrm{g} / \mathrm{ml}: 89.26 \pm 0.27 ; \mathrm{IC}_{50}$ value $19.54 \mu \mathrm{g} / \mathrm{ml}$ 
Table 2: Nitric oxide scavenging activity

\begin{tabular}{ccccc}
\hline Concentration & \multicolumn{5}{c}{ Percentage inhibition } \\
\hline$(\mu \mathrm{g} / \mathrm{ml})$ & $5 \mathrm{a}$ & $5 \mathrm{~b}$ & $5 \mathrm{c}$ & $5 \mathrm{~d}$ \\
\hline 10 & $24.58 \pm 0.70$ & $23.03 \pm 1.27$ & $22.53 \pm 1.03$ & $24.61 \pm 0.23$ \\
20 & $41.67 \pm 0.81$ & $46.80 \pm 0.90$ & $45.56 \pm 0.66$ & $46.95 \pm 1.09$ \\
30 & $53.39 \pm 0.50$ & $56.06 \pm 1.11$ & $57.28 \pm 1.02$ & $57.98 \pm 1.04$ \\
40 & $65.39 \pm 0.87$ & $67.01 \pm 0.33$ & $65.11 \pm 0.70$ & $66.23 \pm 1.37$ \\
50 & $73.18 \pm 0.69$ & $73.56 \pm 0.42$ & $74.99 \pm 1.27$ & $74.63 \pm 0.64$
\end{tabular}

Reference standard - ascorbic acid

Concentration and percentage inhibition of ascorbic acid: $10 \mu \mathrm{g} / \mathrm{ml}: 28.71 \pm 0.10$ $20 \mu \mathrm{g} / \mathrm{ml}: 42.99 \pm 0.02,30 \mu \mathrm{g} / \mathrm{ml}: 54.21 \pm 0.09,40 \mu \mathrm{g} / \mathrm{ml}: 68.21 \pm 0.04$ and $50 \mu \mathrm{g} / \mathrm{ml}$ $78.21 \pm 0.04 ; \mathrm{IC}_{50}$ value $27.21 \mu \mathrm{g} / \mathrm{ml}$

Table 3: Percentage inhibition of the compounds on MCF-7 cell lines

\begin{tabular}{ccccc}
\hline Concentration & \multicolumn{5}{c}{ Percentage inhibition } \\
\hline$(\mu \mathrm{g} / \mathrm{ml})$ & $5 \mathrm{a}$ & $5 \mathrm{~b}$ & $5 \mathrm{c}$ & $5 \mathrm{~d}$ \\
\hline 100 & $68.14 \pm 2.31$ & $75.08 \pm 1.08$ & $72.27 \pm 0.77$ & $70.74 \pm 0.30$ \\
50 & $59.46 \pm 1.66$ & $65.42 \pm 0.35$ & $66.87 \pm 0.44$ & $62.79 \pm 1.16$ \\
25 & $45.80 \pm 1.56$ & $46.76 \pm 1.39$ & $47.55 \pm 0.67$ & $39.44 \pm 0.24$ \\
12.5 & $32.16 \pm 1.80$ & $29.16 \pm 0.64$ & $34.23 \pm 1.56$ & $23.52 \pm 0.90$ \\
6.25 & $16.28 \pm 1.59$ & $20.44 \pm 0.30$ & $14.49 \pm 0.93$ & $13.26 \pm 0.77$ \\
\hline
\end{tabular}

Reference standard - Tamoxifen

Concentration and percentage inhibition of Tamoxifen: $100 \mu \mathrm{g} / \mathrm{ml}: 64.21 \pm 0.04$, $50 \mu \mathrm{g} / \mathrm{ml}: 53.21 \pm 0.56,25 \mu \mathrm{g} / \mathrm{ml}: 45.24 \pm 0.24,12.5 \mu \mathrm{g} / \mathrm{ml}: 31.98 \pm 0.32$ and 6.25 $\mu \mathrm{g} / \mathrm{ml}: 19.71 \pm 0.12 ; \mathrm{CTC}_{50}$ value $38.6 \mu \mathrm{g} / \mathrm{ml}$

Table 4: Percentage inhibition of the compounds on BT-549 cell lines

\begin{tabular}{ccccc}
\hline Concentration & \multicolumn{5}{c}{ Percentage inhibition } \\
\hline$(\mu \mathrm{g} / \mathrm{ml})$ & $5 \mathrm{a}$ & $5 \mathrm{~b}$ & $5 \mathrm{c}$ & $5 \mathrm{~d}$ \\
\hline 100 & $79.10 \pm 1.41$ & $81.55 \pm 1.26$ & $85.55 \pm 0.50$ & $70.63 \pm 0.39$ \\
50 & $70.24 \pm 1.16$ & $69.01 \pm 0.81$ & $66.56 \pm 0.41$ & $60.39 \pm 1.24$ \\
25 & $56.42 \pm 1.93$ & $58.45 \pm 1.31$ & $57.15 \pm 0.17$ & $37.16 \pm 0.46$ \\
12.5 & $44.96 \pm 1.60$ & $38.62 \pm 0.73$ & $43.92 \pm 1.03$ & $21.32 \pm 0.68$ \\
6.25 & $31.36 \pm 1.24$ & $22.18 \pm 0.35$ & $23.10 \pm 0.35$ & $15.96 \pm 0.8$ \\
\hline
\end{tabular}

Reference standard- Tamoxifen

Concentration and percentage inhibition of Tamoxifen: $100 \mu \mathrm{g} / \mathrm{ml}: 66.21 \pm 1.45$, $50 \mu \mathrm{g} / \mathrm{ml}: 48.74 \pm 1.86,25 \mu \mathrm{g} / \mathrm{ml}: 41.94 \pm 1.37,12.5 \mu \mathrm{g} / \mathrm{ml}: 36.38 \pm 0.67$ and $6.25 \mu \mathrm{g} / \mathrm{ml}: 27.11 \pm 1.22 ;$ CTC $_{50}$ value $54.3 \mu \mathrm{g} / \mathrm{ml}$

inactive dead cells. This assay therefore depends on both the number of viable cells present and mitochondrial activity per cell.

The results shown in Tables 3 and 4 suggest a dose-dependent increase in the percentage cell inhibition. A plot of concentration versus percentage inhibition yielded the $\mathrm{CTC}_{50}$ values of the compounds (data not shown). All the compounds exhibited moderate to potent cytotoxic activity. It is seen from the data that isatin derivatives show greater activity than the quinazoline derivatives studied earlier in our group. ${ }^{28}$ Among the target isatins, 5a exhibited maximum activity in both cell lines with $\mathrm{CTC}_{50}$ value of $50.33 \mu \mathrm{g} / \mathrm{ml}$ in MCF-7 cell line and $24.73 \mu \mathrm{g} / \mathrm{ml}$ in BT-549 cell line. This may be due to higher electronegativity of the flourine atom. Such an explanation is plausible due to similar finding by other research groups in revealing the superiority of the fluorine atom over a variety of eletron withdrawing groups as well as in recognizing the importance of

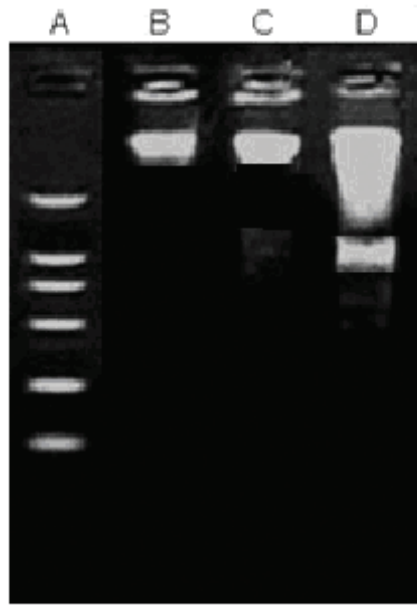

Lane A: DNA ladder; Lane B: MCF-7 cell line (untreated); Lane C: MCF-7 cells treated with 50 $\mu \mathrm{g} / \mathrm{ml}$ of $5 \mathbf{a} \&$ Lane D: MCF-7 cells treated with $100 \mu \mathrm{g} / \mathrm{ml}$ of $\mathbf{5 a}$

Figure 2: Apoptotic effect of $\mathbf{5 a}$ against MCF-7 cell line

fluorine substitution in the para regiochemistry ${ }^{29,30}$ in the context of the both breast and colon cancers. All compounds other than 5a seem to have moderate cytotoxic activity against mammary carcinoma cell lines. The nitro substitutent affords the least cytotoxic activity among the four compounds.

Improper cell death constitutes a major factor in the progression of cancer. One of the aspects in our current research on isatins is to look into the involvement of disrupted apoptosis in tumor formations and to hopefully develop a novel agent for apoptosis modulation. Apoptosis has been characterized biochemically by activation of endonuclease that cleaves the DNA into multimers and can be visualized as oligosomal ladder by standard agarose gel electrophoresis. In order to define the signal transduction pathway leading to apoptosis, sensitive detection of initial endonuclease-mediated DNA strand breaks is an essential first step. DNA fragmentation by DNA ladder assay allows one to determine the amount of DNA that is degraded upon treatment of cells with certain agents. It is evident from Figure 2 that DNA gets fragmented upon treatment with $5 \mathbf{a}$ at doses of 50 and $100 \mu \mathrm{g} / \mathrm{ml}$. From this we can conclude that at 50 and $100 \mu \mathrm{g} / \mathrm{ml}$ doses, the fluorine-substituted congener induces apoptosis in MCF-7 cell lines.

\section{CONCLUSION}

The antioxidant and cytotoxic activities of selected isatin derivatives have been investigated in this study. The data reveals that the fluoro derivative 5a has good cytotoxic activity against breast cancer cell lines. Moreover, 5a seems to induce apoptosis in MCF-7 cell lines and its apoptotic activity is likely attributable to activation of the mitochondrial pathway. However, pre-clinical studies aimed at ensuring the safety and efficacy of this compound are necessary before taking it further.

\section{CONFLICT OF INTEREST}

The authors declare no conflict of interest.

\section{ACKNOWLEDGEMENT}

The authors would like to thank Dr.Sabitha M, Principal, Amrita School of Pharmacy, Amrita Vishwa Vidyapeetham University, AIMS Kochi for providing necessary lab facilities and also we are thankful to Dr. Prasanna Ramani, Department of Science, Amrita Vishwa Vidyapeetham University, Coimbatore for the support of Spectral analysis. 


\section{ABBREVIATIONS USED}

CTC $_{50}$ : Cytotoxic Concentration; IC $_{50}$ : Inhibitorry Concentration.

\section{REFERENCES}

1. Sridhar SK, Saravanan M, Ramesh A. Synthesis and antibacterial screening of hydrazones, Schiff and Man-nich base isatin derivatives. Eur J Med Chem. 2001;36:615-25. https://doi.org/10.1016/S0223-5234(01)01255-7.

2. Bhattacharya SK, Chakrabarti S. Dose related proconvulsant and anticonvulsant activity of isatin, a putative biological factor in rats. Indian J Exp Biol. 1998; 36:118-21. PMid:9536661.

3. Sriram D, Yogeeswari P, Meena K. Synthesis, anti-HIV and antitubercular activities of isatine derivatives. Pharmazie. 2006;61:274-7. PMid:16649536.

4. Chinnasamy RP, Sundarrajan R, Govindaraj S. Synthesis, characterization and analgesic activity of novel Schiff base of isatin derivatives. J Adv Pharma Technol Res. 2010;13:342-7. https://doi.org/10.4103/0110-5558.72428 PMid:22247869 PMCid:PMC3255410.

5. Mondal P, Banerjee M, Jana S, Bose A. Synthesis and evaluation of 1,3 disubstituted Schiff, Mannich bases and spiro isatin derivatives. J Young Pharm. 2010;2:169-72. https://doi.org/10.4103/0975-1483.63164 PMid:21264121 PMCid:PMC3021693.

6. Zhang HM, Dai H, Hanson PJ, Guo H, Ye X, Hemida MG, Wang L, Tong Y, Qiu Y, Liu S, Wang F, Song F, Zhang B, Wang JG, Zhnag LX, Yang D. Antiviral activity of an isatin derivative via induction of PERK-Nrf2-mediated suppression of capindependent translation. ACS Chem Biol. 2014;9:1015-24. https://doi.org/ 10.1021/cb400775z PMid:24547890.

7. Selvam P, Murugesh N, Chandramohan M, Debyser Z, Witvrouw M. Design, synthesis and anti-HIV activity of isatin-sulphonamides. Indian J Pharm Sci. 2008;70:779-82. https://doi.org/10.4103/0250-474X.49121 PMid:21369440 PMCid:PMC3040873

8. Kupinic M, Medic-Škaric M, Movrin M, Maysinger D. Antibacterial and antifungal activities of isatin N-Mannich bases. J Pharm Sci. 1979; 68:459-62. [9] Jemal A, Brey F, Center MM, Ferlay J, Ward E, Forman D. Global cancer statistics. CA Cancer J Clin. 2011;61:69-90. https://doi.org/10.3322/caac.20107 PMid:21296855

9. Jemal A, Brey F, Center MM, Ferlay J, Ward E, Forman D. Global cancer statistics. CA Cancer J Clin. 2011;61:69-90. https://doi.org/10.3322/caac.20107 PMid:21296855

10. Samphao S, Wheeler AJ, Rafferty E, Michaelson JS, Specht MC, Gadd MA Hughes KS, Smith BL. Diag-nosis of breast cancer in women age 40 and younger: delays in diagnosis result from underuse of genetic testing and breast imaging. Am J Surg. 2009;198:538-43. https://doi.org/10.1016/j.amjsurg.2009.06.010 PMid: 19800464

11. Kwan ML, Kushi LH, Weltzein E, Maring B, Kutner SE, Fulton RS, Lee MM, Ambrosone CB, Caan BJ. Epidemiology of breast cancer subtypes in two prospective cohort studies of breast cancer survivors. Breast Cancer Res 2009; 11:1-13. https://doi.org/10.1186/bcr2261 PMid:19463150 PMCid:PMC2716499.

12. Makin G and Dive C. Apoptosis and cancer chemotherapy. Trends Cell Biol 2001;11:22-6. https://doi.org/10.1016/S0962-8924(01)82111-5 https://doi. org/10.1016/S0962-8924(01)02124-9.

13. Lee WR, Shen SC, Lin HY, Hou WC, Yang LL, Chen YC. Wogonin and fisetin induce apoptosis in human promyeloleukemic cells, accompanied by a decrease of reactive oxygen species, and activation of caspase 3 and Ca2+-dependent endonuclease. Biochem Pharmacol. 2002;63:225-36. https://doi.org/10.1016/ S0006-2952(01)00876-0.

14. Yogeeswari $P$, Ragavendran JV, Thirumurugan $R$, Induja S, Sriram D, Stables JP Synthesis and structure-activity relationship on anticonvulsant aryl semicarbazones. Med Chem. 2006;2:55-62. https://doi.org/10.2174/157340606775197778 PMid:16787356
15. Sathianarayanan, Jose A, Balasubramanian R, Thomas D, Balakrishnan A Aiyalu R. Alcoholic Extract of Wrightia tinctoria leaves and Isolates there of afford DNA Protection in Post Irradiated Sprague Dawley Rats. J Young Pharm. 2016:8(4):398-405. https://doi.org/10.5530/jyp.2016.4.16.

16. Iqbal $H$, Prabhakar $V$, Sangith A Chandrika B, Balasubramanian R. Synthesis, anti-inflammatory and anti-oxidant activity of ring-A-monosubstituted chalcone derivatives. Med Chem Res. 2014;23:4383-94. https://doi.org/10.1007/s00044014-1007-z.

17. Premanathan M, Radhakrishnan S, Kulangiappar K, Singaravelu G, Thirumalaiarasu $V$, Sivakumar T, Kathiresan K. Antioxidant and anticancer activity of isatin $(1 \mathrm{H}$-indole-2,3-dione) isolated from the flowers of Couroupita guianensis Aubl. Indian J Med Res. 2010;136:822-6.

18. Nitin VG. In-vitro antioxidant activity of Zanthoxylum armatum leaves. Indian J Nat Prod. 2008;24:3-9

19. Denizot F, Lang R. Rapid colorometric assay for cell growth and survival: Modifications to the tetrazolium dye procedure giving improved sensitivity and reliability. J Immunol Methods. 1986;89:271-7. https://doi.org/10.1016/0022 1759(86)90368-6.

20. Kamal A, Bharathi EV, Reddy JS, Ramaiah MJ, Dastagiri D, Reddy MK Viswanath A, Reddy TL, Shaik TB, Pushpavalli SNCVL, Bhadra MP. Synthesis and biological evaluation of 3,5-diaryl isoxazoline/isoxazole linked 2,3-dihydroquinazolinone hybrids as anticancer agents. Eur J Med Chem. 2011;46:691-703. https://doi.org/10.1016/j.ejmech.2010.12.004 PMid:21194809.

21. Jose $A$, Chittethu AB, Sankaran S, Saranya TS, Ekambaran KP. Synthesis and characterization of quinazo-linone derivatives against mammary carcinoma. J Pharm Res. 2013;6:933-8. https://doi.org/10.1016/j.jopr.2013.07.033.

22. Bharath Kumar S, Ravinder M, Kishore G, Rao V D, Yogeeswari P, Sriram D. Synthesis, antitubercular and anticancer activity of new Baylis-Hillman adduct-derived $\mathrm{N}$-cinnamyl-substituted isatin derivatives. Med Chem Res. 2014;23:1934-40. https://doi.org/10.1007/s00044-013-0787-x.

23. Skehan P, Storeng R, Scudiero D, Monks A, McMahon J, Vistica D, Warren JT Bokesch H, Kenney S, Boyd MR. New colorimetric cytotoxic assay for anti cancer drug screening. J Nat Cancer Inst. 1990:82:1107-12. https://doi. org/10.1093/jnci/82.13.1107 PMid:2359136.

24. Dey SK, Bose D, Hazra A, Nazkar S, Nandy A, Munda RN, Das S, Chatterjee N Mondal NB, Banerjee S, Saha KD. Cytotoxic activity and apoptosis-inducing potential of di-spiropyrrolidino and di-spiropyrrolizidino oxindole andrographolide derivatives. PLOS one. 2013;8:e58055. https://doi.org/10.1371/journal. pone.0058055 PMid:23472133 PMCid:PMC3589478.

25. Basnakian AG, James SJ. A rapid and sensitive assay for the detection of DNA fragmentation during early phases of apoptosis. Nucl Acids Res. 1994;22:2714-5. https://doi.org/10.1093/nar/22.13.2714

26. Yu BP. Cellular defenses against damage from reactive oxygen species. Physiol Rev. 1994;74:139-62. PMid:8295932.

27. Lerman A, Burnett JC. Intact and altered endothelium in regulation of vasomotion Circulation. 1992;8:12-9.

28. Flitney FW, Pritchard RJ, Kennovin GD, Bisland SK, Hirst DG, Fricker SP. Anti tumor actions of rutheni-um(III)-based nitric oxide scavengers and nitric oxide synthase inhibitors. Mol Cancer Ther. 2011:10:1572-80. https://doi. org/10.1158/1535-7163.MCT-10-0840 PMid:21712476.

29. Abdou IM, Saleh AM, Zohdi HF. Synthesis and antitumor activity of 5-triflouromethyl-2,4-dihydropyrzole-3-one nucleosides. Molecules. 2004;9:109-16. https://doi.org/10.3390/90300109 PMid:18007415.

30. Mortimer CG, Wells G, Crochard JP, Stone EL, Bradshaw TD, Stevens MFG Westwell AD Antitumor benzothiazoles. 26.(1) 2-(3,4-dimethoxyphenyl)-5-flourobenzothiazole (GW 610, NSC 721648), a simple flouri-nated 2-arylbenzothiazole, shows potent and selective inhibitory activity against lung, colon and breast cancer cell lines. J Med Chem. 2006;49:179-85. https://doi.org/10.1021/ jm050942k PMid:16392802

Article History: Submission Date: 16-09-16; Received Date: 01-10-16; Acceptance Date: 28-12-16.

Cite this article: Sathianarayanan, Chittethu AB, Jose A, Balasubramanian R, Saranya TS1, Manakadan AA. Utility of Isatin Semicarbazones in Mammary Carcinoma Cells-A Proof of Concept Study. J Young Pharm. 2017;9(2):218-23. 